\title{
Acetone extract from Streptoverticillium sp., a bacterium isolated from Brazilian Cerrado soil, induces anti-inflammatory activity in mice
}

\author{
RODRIGO B. DA CRUZ ${ }^{2}$, PABLINNY M. GALDINO ${ }^{2}$, KARLLA G.B.D. PENNA ${ }^{1}$, \\ KAREN HOFFMANN ${ }^{1}$, ELSON A. COSTA ${ }^{2}$ and LUIZ A.M. BATAUS ${ }^{1}$ \\ ${ }^{1}$ Laboratório de Bioquímica e Engenharia Genética, Departamento de Ciências Fisiológicas, Instituto de Ciências Biológicas, \\ Universidade Federal de Goiás, Campus Samambaia, Rua do Campus, s/n, Setor Samambaia, 74001-970 Goiânia, GO, Brasil \\ ${ }^{2}$ Laboratório de Farmacologia de Produtos Naturais, Departamento de Ciências Fisiológicas, Instituto de Ciências Biológicas, \\ Universidade Federal de Goiás, Campus Samambaia, Rua do Campus, s/n, 74001-970 Goiânia, GO, Brasil
}

Manuscript received on September 21, 2011; accepted for publication on April 10, 2012

\begin{abstract}
The Streptoverticillium sp. Z1 is an actinomycete isolated from the soil under Cerrado vegetation, the extract of this strain was investigated in nociceptive and inflammatory models. The Streptoverticillium extract (ExS) 50 and $100 \mathrm{mg} / \mathrm{kg}$ (s.c.) produced a significant inhibition of acetic acid-induced abdominal writhings thereby demonstrating an anti-nociceptive effect. In the tail flick test the ExS (s.c.) was inactive. This result implited that ExS does not contain opioid-like compounds with central analgesic properties. In the inflammatory models, ExS 100 and $200 \mathrm{mg} / \mathrm{kg}$ (s.c.) were able to inhibit the croton oil-induced ear edema and, ExS 200 and $500 \mathrm{mg} / \mathrm{kg}$ (s.c.) inhibited the leukocyte migration on the carrageenan-induced peritonitis. The phospholipase $\mathrm{A}_{2}$ enzymatic assay showed that the anti-inflammatory activity of ExS was not due to direct effect on phospholipase $\mathrm{A}_{2}$ activity. These data suggest that Streptoverticillium $s p$. produces metabolites with antiinflammatory effect and that these metabolites are unable to directly inhibit phospholipase $A_{2}$ enzyme.
\end{abstract}

Key words: Streptoverticillium, anti-inflammatory effect, nociceptive and inflammatory models, phospholipase $\mathrm{A}_{2}$ activity.

\section{INTRODUCTION}

Inflammation is a natural host-defensive process in the innate immunity response and is usually associated with pain as a secondary process resulting from the release of algesic mediators (Hunskaar and Hole 1987, Osadebe and Okoyé 2003). Generally, the inflammatory process involves a series of events that can be elicited by numerous stimuli such as infectious agents, ischaemia, antigen-antibody interaction and thermal or physical injury (Osadebe

Correspondence to: Elson Alves Costa

E-mail: xico@icb.ufg.br and Okoyé 2003, Insel 1990). Acute inflammation is a rapid and securely self-terminating process that can, however, be harmful to the host if subclinical inflammation survives and it is followed by the development of local chronic inflammation. Such inflammation provides a cellular microenvironment that favors malignant progressions such as tumor promotion (Balkwill et al. 2005).

Biotechnology research is a viable and promising means of obtaining new substances, for example, from the study of microorganisms. The biochemical heterogeneity of actinomycetes, their ecological 
diversity and its exceptional ability to produce secondary metabolites make them a suitable target for the discovery of new substances that have biological activity of biotechnological interest (Peckyñska-czoch and Mordarski 1988).

The Streptoverticillium sp. Z1 is an actinomycete isolated from soil under Cerrado vegetation, belonging to the microbial culture collection of the Laboratory of Biochemistry and Genetic Engineer, Biologic Sciences Institute Universidade Federal de Goiás. This microorganism produces substances with antimicrobial activity (K. Hoffmann et al., unpublished data), chitinase and N-acetylglucosaminidase (I.S. Sobrinho, unpublished data). K. Hoffmann et al. (unpublished data) demonstrated that Streptoverticillium sp. Z1 provides a qualitative and quantitative variation in the production of antimicrobial substances when grown in different culture medium. Hence, the aim of this study is to assay the anti-inflammatory activity of cell biomass extracts of Streptoverticillium culture in different methodologies.

\section{MATERIALS AND METHODS}

\section{DRUGS AND REAGENTS}

The following drugs were used: acetic acid (1.2\%; Merck; $10 \mathrm{~mL} / \mathrm{kg})$, carrageenan solution (1\%; Sigma; $0.25 \mathrm{~mL} /$ animal), croton oil (Prodome), dexamethasone (Decadron-Prodome; $2 \mathrm{mg} / \mathrm{kg}$ ), morphine (Roche, Switzerland; $5 \mathrm{mg} / \mathrm{kg}$ ), indomethacin (Sigma; $10 \mathrm{mg} / \mathrm{kg}$ ), and egg yolk (Newprov, Brazil). All other reagents used were of analytical grade and were obtained from Synth (Brazil). Crotallus durissus collilineatus venom was kindly provided by Marta R. Magalhães, Laboratory of Toxinology of the Center for Biologic Studies and Research - PUC Goiás, Brazil.

\section{STREPTOVERTICILLIUM SP. Z1 STRAIN}

The Streptoverticillium sp. Z1, belonging to the microbial culture collection of Laboratory of
Biochemistry and Genetic Engineer, Biologic Sciences Institute, Universidade Federal de Goiás, was isolated from soil of the Brazilian cerrado.

MaINTENANCE AND CULTIVATION OF THE ISOLATED STRAIN

The Streptoverticillium sp. Z1 was kept isolated in Petri dishes containing ISP-2 medium (glucose 4.0 $\mathrm{g} / \mathrm{L}$; Yeast extract $4.0 \mathrm{~g} / \mathrm{L}$; Malt extract $10.0 \mathrm{~g} / \mathrm{L}$; Agar $20.0 \mathrm{~g} / \mathrm{L}, \mathrm{pH} 7.2$ ) at $30^{\circ} \mathrm{C}$. This microorganism was grown in 2,000 mL Erlemayer flask containing $500 \mathrm{~mL}$ of medium MPE (soy flour $20.0 \mathrm{~g} / \mathrm{L}$; glucose $20.0 \mathrm{~g} / \mathrm{L} ; \mathrm{CaCO} 32.0 \mathrm{~g} / \mathrm{L} ; \mathrm{NaCl} 5.0 \mathrm{~g} / \mathrm{L}$, $\mathrm{pH}$ 7.0), and incubated at $30^{\circ} \mathrm{C}$ under constant agitation at $150 \mathrm{rpm}$ for 10 days.

EXTRACT PRODUCTION

The medium was vacuum filtrated (Whatman number 1 filter) then the liquid phases were discarded and the resulted biomass was resuspended in acetone and maintained in agitation for two hours to extract the polar compounds and pigments. The acetone extract obtained (acetone with cell biomass) was concentrated under reduced pressure resulting in the Streptoverticillium acetone extract $($ ExS). This extract was reconstituted in saline $(\mathrm{NaCl} 0.9 \%)$ at the required concentrations for pharmacological tests.

\section{ANIMALS}

Male Swiss albino mice weighing approximately $35 \mathrm{~g}$ from the Central Animal House of the Universidade Federal de Goiás (UFG) were used in this study. The animals received food and water ad libitum and were maintained in a room with light and temperature regulation. All experimental protocols were developed in accordance with the principles of ethics and animal welfare designated by the Brazilian College of Animal Experiments (COBEA/ SBCAL) and the experimental protocols were approved by the Ethics Commission of the Hospital das Clínicas - UFG (\# 147/2008). 


\section{EFFECT ON GROSS BEHAVIOR}

The effect on spontaneous mouse behavior was determined using the Hippocratic procedure (Malone 1977). Groups of eight adult albino mice were treated per orus (p.o.), subcutaneously (s.c.) and intraperitoneally (i.p.) with vehicle $(0.9 \% \mathrm{NaCl}, 10$ $\mathrm{mL} / \mathrm{kg}$ ) or ExS 1,10 and $100 \mathrm{mg} / \mathrm{kg}$ and kept under observation for seven days. With this method the doses and administration route were defined.

\section{ANTI-NOCICEPTIVE ACTIVITY}

\section{Acetic acid-induced abdominal writhing test}

The response to an intraperitoneal injection of acetic acid solution (i.e. the contractions of the abdominal muscles and stretching of hind limbs) was studied according to Koster et al. (1959) and Hendershot and Forsarth (1959). Experimental groups of mice $(n=8)$ were treated subcutaneously with vehicle $(10 \mathrm{~mL} / \mathrm{kg})$, ExS 50 and $100 \mathrm{mg} / \mathrm{kg}$, or indomethacin $(10 \mathrm{mg} / \mathrm{kg})$, as positive control, $30 \mathrm{~min}$ before the administration of a $1.2 \%(\mathrm{v} / \mathrm{v})$ acetic acid solution $(10 \mathrm{~mL} / \mathrm{kg}$, i.p.). The number of writhes produced in each group was counted during 30 min of observation. The results obtained were expressed as the percentages relative to the control group. A significant reduction in the number of writhing movements in the groups treated with ExS compared with the control was considered to be a positive anti-nociceptive response.

\section{Tail flick test}

The reaction of mice to thermal stimulation of the tail tip by immersion in water maintained at 55.5 $\pm 0.5^{\circ} \mathrm{C}$ was recorded at $-30,-15,0,15,30,45,60$ minutes of treatment. Experimental groups of mice $(\mathrm{n}=8)$ were treated with vehicle $(10 \mathrm{~mL} / \mathrm{kg}$, s.c.), ExS 50 and $100 \mathrm{mg} / \mathrm{kg}$ (s.c.), or morphine $5 \mathrm{mg} / \mathrm{kg}$, (s.c.), as positive control. The anti-nociceptive data were expressed as mean $\pm \mathrm{SEM}$, relative to 0 time, according to the technique of Janssen et al. (1963), as modified by Grotto and Sulman (1967).
ANTI-INFLAMMATORY ACTIVITY

\section{Croton oil-induced ear edema test}

The animals were treated (s.c.) with vehicle $(10 \mathrm{~mL} /$ $\mathrm{kg}$ ), dexamethasone $(2 \mathrm{mg} / \mathrm{kg})$, or ExS 100 and $200 \mathrm{mg} / \mathrm{kg}(\mathrm{n}=8)$, and $60 \mathrm{~min}$ later, cutaneous inflammation was induced by applying $25 \mu \mathrm{L}$ of croton oil $(2.5 \% \mathrm{v} / \mathrm{v}$ in acetone $)$ solution to the inner surface of the right ears of the mice. The same volume of acetone was applied to the left ears by the method of Tubaro et al. (1985) and Zanini et al. (1992). Four hours after treatment, mice were killed by cervical dislocation, and a plug $(6 \mathrm{~mm}$ in diameter) was taken from both treated and untreated ears with a punch. The inflammatory response (edema) was monitored by measuring the differences in weight $(\mathrm{mg})$ between the two plugs $(\Delta)$. The results were expressed as the percentages relative to the control group.

\section{Carrageenan-induced peritonitis test}

Animals were treated (s.c.) with vehicle $10 \mathrm{~mL} / \mathrm{kg}$, dexamethasone $2 \mathrm{mg} / \mathrm{kg}$ or ExS 200 and $500 \mathrm{mg} /$ $\mathrm{kg}(\mathrm{n}=8) 45 \mathrm{~min}$ before an injected of carrageenan $(1 \%$; $0.25 \mathrm{~mL}$, i.p.). Four hours after carrageenan administration, mice were killed and $2 \mathrm{~mL}$ of modified PBS (with heparin, $10 \mathrm{IU} / \mathrm{mL}$, and without calcium and magnesium) was injected into the peritoneal cavity. Total cell counts in the lavage fluid were performed in a Neubauer chamber (Ferrándiz and Alcaraz 1991). The results were expressed as the percentages relative to the control group.

\section{Phospholipase $A_{2}$ Enzymatic Assay}

To assay the inhibition activity of ExS on PLA activity we used a modified method based on Harbermann and Hardt (1972). Briefly, the $\mathrm{PLA}_{2}$ activity was evaluated by the hemolysis of erythrocytes suspension incorporated into agarose gels. Agar plates $(0.8 \%)$ were prepared with $30 \mathrm{~mL}$ of Tris- $\mathrm{HCl} 0.05 \mathrm{M}$ buffer, $0.25 \mathrm{~mL}$ of $\mathrm{CaCl}_{2} 0.01 \mathrm{M}$, 
$0.3 \mathrm{~mL}$ of egg yolk in saline (1:4) and $0.3 \mathrm{~mL}$ human erythrocytes washed. $7.5 \mu \mathrm{L}$ of Crotallus durissus collilineatus venom solution $(0.03 \mathrm{mg} / \mathrm{mL})$ plus an equal volume of $\operatorname{ExS}(50 \mathrm{mg} / \mathrm{mL})$, dexamethasone $(0.2 \mathrm{mg} / \mathrm{mL})$ or indomethacin solutions $(1 \mathrm{mg} / \mathrm{mL})$ were incubated at $37^{\circ} \mathrm{C}$ for one hour. Afterwards, the incubated was placed in $2 \mathrm{~mm}$ of diameter equidistance well and the plates were incubated at $37^{\circ} \mathrm{C}$ for 20 hours. After incubation the halos produced by hemolysis ( $\mathrm{PLA}_{2}$ activity) were measured. The results were expressed as mean \pm SEM of halo area.

\section{STATISTICAL ANALYSIS}

All the results were expressed as mean \pm S.E.M. and treated groups were compared with the control and differences were estimated by means of ANOVA followed by Tukey as the post hoc test. All analyses were performed using the software GraphPad Prism 3.0 for Windows. Effects were considered significant at $P<0.05$.

\section{RESULTS}

EFFECT ON GROSS BEHAVIOR

In the general test of pharmacological activity, the animals treated with ExS (s.c. or i.p.) shown antinociception (assessed by pain reaction caused by the compression of distal portion of the tail), increase diuresis and decrease in motor activity (spontaneous ambulation) within 30 min of treatments, in a dose response manner. Other parameters suggested by Malone (1977), indicative of pharmacological activity, and did not show significant difference. The extract was ineffective by the oral route.

ACETIC ACID-INDUCED ABDOMINAL WRITHING

As shown in Figure 1, the ExS 50 and $100 \mathrm{mg} / \mathrm{kg}$ (s.c.) produced a significant inhibition of acetic acidinduced abdominal writhings to $67.95 \pm 2.55 \%$ and $56.85 \pm 5.48 \%$, respectively, and indomethacin (10 $\mathrm{mg} / \mathrm{kg}$ ) produced an inhibition to $48.35 \pm 7.39 \%$ of writhes, from control value of $73.00 \pm 4.8$ writhes.

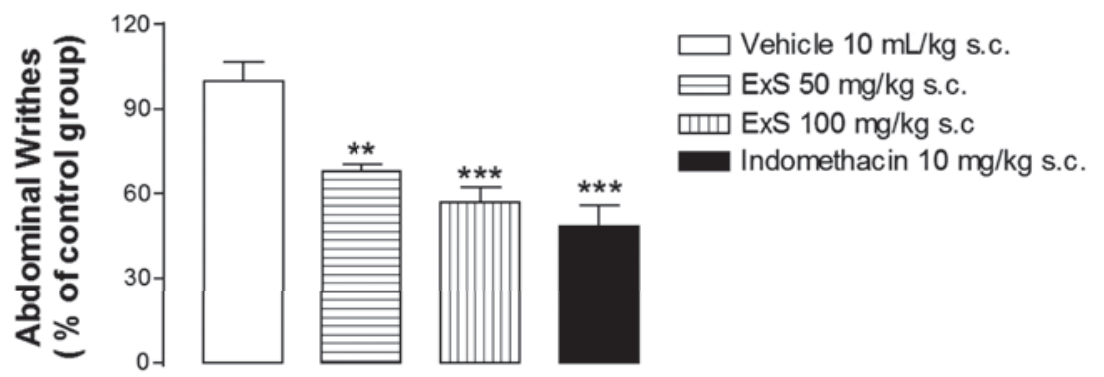

Figure 1 - Effect of Streptoverticillium sp. extract (ExS 50 and $100 \mathrm{mg} / \mathrm{kg}$, s.c.) on the number of acetic acid-induced abdominal writhes in mice. The vertical bars indicate the mean \pm SEM, expressed in relative percentage to the control group. Indomethacin $(10 \mathrm{mg} /$ $\mathrm{kg}$, s.c.) was used as a positive control. ** $p<0.01, * * * p<0.001$, vs control group (vehicle).

\section{TAIL FLICK TEST}

The ExS (s.c.) was inactive in the tail flick test of nociception in both doses tested (50 and $100 \mathrm{mg}$ / $\mathrm{kg}$ ). Morphine, used as a reference drug, produced a significant anti-nociceptive effect at all observation times compared to control group. These results suggest that the ExS does not contain opioid-like compounds with central analgesic properties (Fig. 2).

\section{CROTON OIL-INDUCEd EAR EDEMA Test}

In the Croton oil-induced ear edema test, the ExS 100 and $200 \mathrm{mg} / \mathrm{kg}$ (s.c.) were able to inhibit the edema to $44.77 \pm 2.3 \%$ and $36.14 \pm 3.1 \%$, respectively; from control value of $13.5 \pm 0.84$ $\mathrm{mg}$ of edema. Indomethacin $(10 \mathrm{mg} / \mathrm{kg})$ produced a significant inhibition to $15.03 \pm 3.80 \%$ of the edema (Figure 3). 


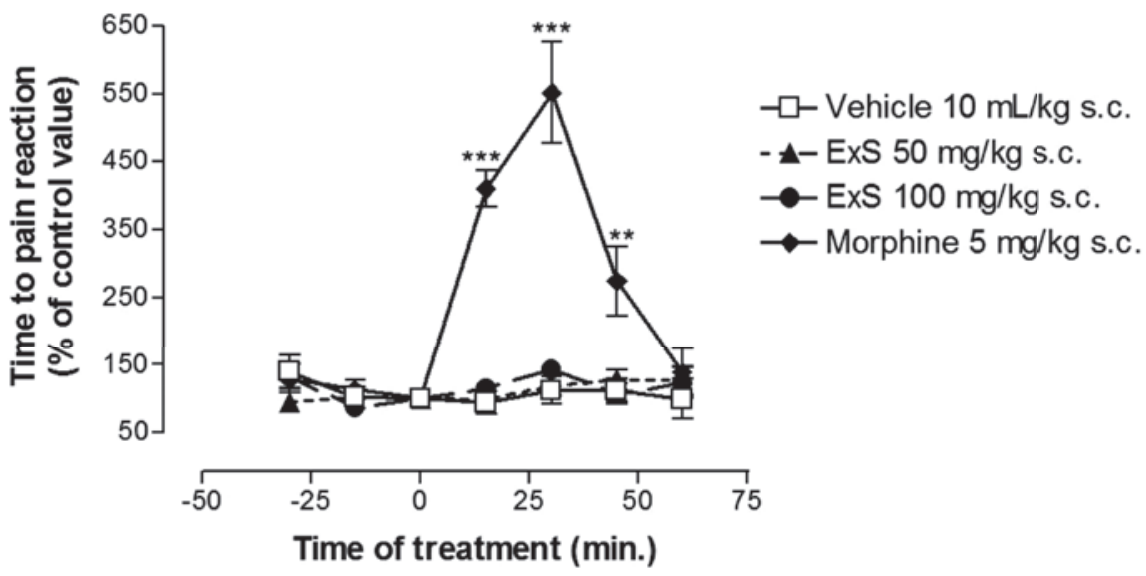

Figure 2 - Effect of Streptoverticillium sp. extract (ExS 50 and $100 \mathrm{mg} / \mathrm{kg}$, s.c.) on the time to pain reaction in mice. The vertical bars indicate the mean $\pm \mathrm{SEM}$, expressed in relative percentage to the control group. Morphine $(5 \mathrm{mg} / \mathrm{kg}$, s.c.) was used as a positive control. $* * p<0.01, * * * p<0.001$, vs control group (vehicle).

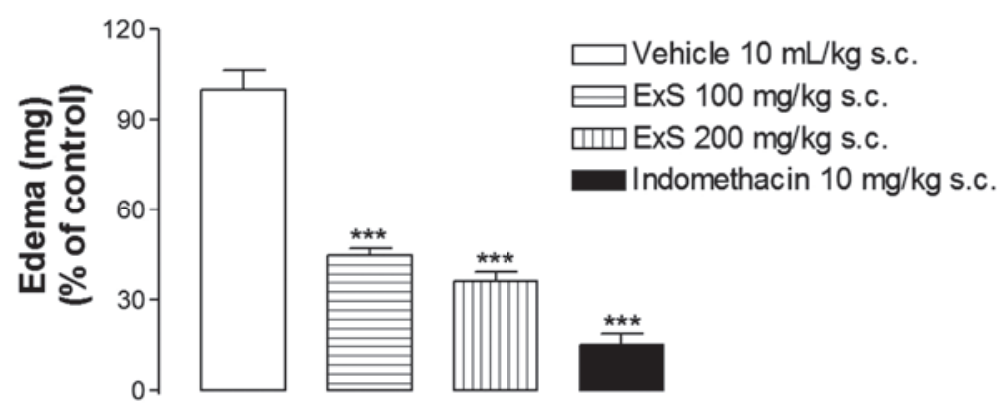

Figure 3 - Effect of Streptoverticillium sp. extracts, ExS 100 and $200 \mathrm{mg} /$ $\mathrm{kg}$, s.c., on croton oil-induced ear edema in mice. The vertical bars indicate the mean \pm SEM of differences in weight between right and left ear plugs. Indomethacin $\left(10 \mathrm{mg} / \mathrm{kg}\right.$, s.c.) was used as a positive control. ${ }^{* * *} p<0.001$, vs control group (vehicle).

\section{CARRAgeEnAN-INDUCED PERITONITIS}

The treatment with ExS significantly reduced the total leukocyte migration to the peritoneum induced by carrageenan compared with control group. ExS administered subcutaneously at doses of 200 and $500 \mathrm{mg} / \mathrm{kg}$ caused inhibition of total leukocyte migration to $45.8 \pm 7.8 \%$ and $29.7 \pm 3.4 \%$, respectively, when compared with control value $1.47 \pm 0.17 \times 10^{7}$ leukocytes $/ \mathrm{mL}$, and dexamethasone $2 \mathrm{mg} / \mathrm{kg}$ inhibited the total leukocyte migrated to $22.25 \pm 3.9 \%$ (Figure 4 ).
PhOSPHOLIPASE A $\mathrm{A}_{2}$ ENZYMATIC ASSAY

In this methodology, ExS and dexamethasone were not able to inhibit the $\mathrm{PLA}_{2}$ activity. Only indomethacin inhibit the halo area to $0.667 \pm 0.1778 \mathrm{~cm}^{2}$ from control value of $0.929 \pm 0.040 \mathrm{~cm}^{2}$ (Table I).

\section{DISCUSSION}

The attention given to the actinomycetes in biotechnological applications is a natural result of the great metabolic diversity of these organisms and their long association with the environment 


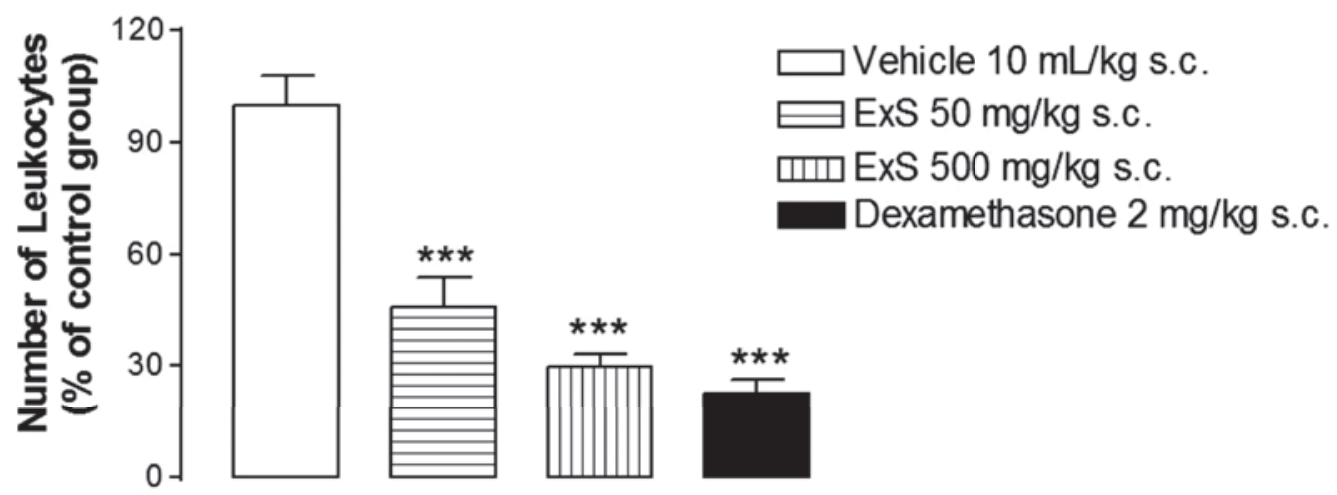

Figure 4 - Effect of Streptoverticillium sp. extracts, ExS 200 and $500 \mathrm{mg} / \mathrm{kg}$, s.c., on carrageenaninduced peritonitis in mice. The vertical bars indicate the mean \pm SEM of total number of leukocytes migrated to peritoneum. Dexamethasone $(2 \mathrm{mg} / \mathrm{kg}$, s.c.) was used as a positive control. *** $p<0.001$, vs control group (vehicle).

TABLE I

Effect of Streptoverticillium sp. extract (ExS), Indomethacin and Dexamethasone onphospholipase $A_{2}$ enzymatic assay in vitro.

\begin{tabular}{c|c|c}
\hline Group & Concentration & $\begin{array}{c}\text { Halo area of } \\
\text { hemolysis } \mathbf{( c m}^{\mathbf{2}} \mathbf{)}\end{array}$ \\
\hline Vehicle & - & $0.930 \pm 0.040$ \\
\hline ExS & $50 \mathrm{mg} / \mathrm{mL}$ & $0.990 \pm 0.070$ \\
\hline Indomethacin & $1 \mathrm{mg} / \mathrm{mL}$ & $0.668 \pm 0.018^{*}$ \\
\hline Dexamethasone & $0.2 \mathrm{mg} / \mathrm{mL}$ & $1.023 \pm 0.062$ \\
\hline
\end{tabular}

Values are mean \pm SEM (of 4 wells) of the halo area of hemolysis $\left(\mathrm{cm}^{2}\right)$ in the presence of Crotallus durissus collilineatus venom $(0.03 \mathrm{mg} / \mathrm{mL}) .{ }^{*} p<0.05$, vs control group.

and human needs. However, it is becoming increasingly difficult to discover commercially significant secondary metabolites from well known actinomycetes as this practice leads to the wasteful rediscovery of already known bioactive compounds, thereby emphasizing the need to isolate, characterize and screen representatives of undiscovered actinomycete taxa. It is also becoming increasingly clear that un- and underexplored habitats, such as desert biomes and marine ecosystems, are rich sources of novel actinomycetes which have the capacity to produce interesting new bioactive compounds, including antibiotics (Bredholt 2008).
The analgesic activity observed in general test of pharmacological activity should be the result of a motor activity reduction, also observed in this same test, thus it became necessary to perform different specific models to assay the analgesic and antiinflammatory effect in order to demonstrate the effects produced with Streptoverticillium biomass extract treatment. Considering that the extract showed activity when administered either by i.p. and s.c. routes, the following tests were conducted with treatments performed by the subcutaneous route because this route is safer to avoid false positive results in some models such as writhing and peritonitis tests.

The antinociceptive effect of Streptoverticillium sp. acetone extract $(\mathrm{ExS})$ was tested in two different models of analgesia, i.e., the acetic acid-induced writhing test and tail flick test in mice. The acetic acid-induced abdominal writhing is commonly used as a screening method for compounds with potential anti-nociceptive and/or anti-inflammator. In this method the injected acetic acid produces nociception directly by stimulation of terminal nervous and indirectly by leading to the release of endogenous mediators involved in pain modulation, for example: bradykinin, serotonin, histamine, prostaglandin (Berkenkopf 
and Weichman 1988, Chau 1989). This is widely used because of the high sensitivity to drugs with anti-nociceptive action in different drug classes such as aspirin, antagonists of kinin receptors, central and peripheral-acting opioid analgesics (Hendershot and Forsaith 1959, Vacher et al. 1964). In this model of nociception, we demonstrated that the previous treatments with ExS was effective both at a dose of 100 and $50 \mathrm{mg} / \mathrm{kg}$ in reducing the abdominal writhes, thereby demonstrating anti-nociceptive and/or anti-inflammatory activity (Figure 1). In order to evaluate the involvement of a central antinociceptive activity, the same doses of ExS were used in the tail flick test.

In the tail flick test, morphine is used to induce analgesia. Within 1-30 min, when morphine induced maximum analgesia, since its response involves essentially spinal receptors $\left(\mu_{2}, \kappa_{1}, \delta_{2}\right)$ (Reisine and Pasternack 1996). ExS did not produce any analgesia suggesting that its extract has no central analgesic properties (Figure 2). Therefore, it is not probable that ExS exerted its effect through central opioid receptors or promoted release of endogenous opiopeptides.

It is known that the acute inflammatory response consists of three main vascular effects: (I) vasodilatation and increasing vascular flow; (II) increased vascular permeability; and (III) leukocyte migration to the injured tissues. Therefore, the antiinflammatory activity of ExS was evaluated on the croton oil-induced ear edema and carrageenaninduced peritonitis tests. In these inflammation models, higher doses (100 and $200 \mathrm{mg} / \mathrm{kg}$ ) were used taking into account the lower sensitivity of these methodologies used.

The croton oil-induced ear edema was carried out by topical application of a phlogistic agent to the inner surface of the ear. A reduction in this edema as a result of ExS treatment was assessed as a parameter of anti-inflammatory activity.

The inhibition of croton oil-induced ear edema caused by treatment with ExS (Figure 3) may be associated with interference in factors that influence edema formation such as tissue vascular flow and systemic blood pressure (Rates and Barros 1994) and prostaglandins synthesis, important to the genesis of edema and pain (Morrow and Roberts 2001).

Considered that an inhibitory activity only on cyclooxygenase activity has less potential to reduce cell migration and can reduce ear edema, we decided to raise the dose in the peritonitis model.

In the carrageenan-induced peritonitis, the carrageenan administration act as a stimulus to produce an acute inflammatory response after 4 hours in the peritoneal cavity of mice, with a large number of leukocytes in the exudate. The treatment with ExS inhibited cell migration to the peritoneal cavity in a significant manner when compared with the control group (Figure 4). The results in these two methods suggest that ExS may contain active compounds with anti-inflammatory effects.

The anti-inflammatory effect of a drug may occur by different mechanisms of action among which there are the inhibition cyclooxygenase (COX) or phospholipase $\mathrm{A}_{2}\left(\mathrm{PLA}_{2}\right)$. The inhibition of $\mathrm{PLA}_{2}$ in vivo is an important mechanism in the anti-inflammatory effect of glucocorticoids, this enzyme can also be inhibited directly as occur with indomethacin (Lobo and Hoult 1994, Singh et al. 2009) or indirectly by induction of protein synthesis as occurs with dexamethasone (Flower and Blackwell 1979).

Meanwhile, phospholipase $\mathrm{A}_{2}$ enzymatic assay was performed in order to evaluate possible direct inhibitory effect of ExS on PLA 2 activity, and try to propose a mechanism of action. In the in vitro model, the drugs solutions were used at the same concentrations as they were used in the in vivo test, and the extract solution was used at the same concentration prepared to in vivo highest dose.

As expected, dexamethasone in this in vitro test cannot inhibit the $\mathrm{PLA}_{2}$ activity, because this inhibition involves cellular mechanisms such as 
protein synthesis of anexin-1 and gene regulation, that cannot occur in the absence of cellular activity (Schimmer and Parker 1996) and indomethacin inhibited the $\mathrm{PLA}_{2}$ activity because this inhibition is due to its direct binding to the enzyme (Lobo and Hoult 1994, Singh et al. 2009). ExS present no inhibition on $\mathrm{PLA}_{2}$ activity (Table I).

The ExS anti-edematogenic effect shown should be due to a mechanism of action similar to indomethacin by reducing the activity of the cyclooxygenase enzyme as well as a decrease of its expression. On the other hand, an inhibitory effect dependent of cellular mechanisms on PLA2 activity in a similar way as dexamethasone or reduction in expression or inhibition of lipoxygenase could explain the reduction in cell migration observed with ExS treatment on peritonitis model.

The ExS concentration used in the in vitro model is certainly higher than the concentration achieved by the active principles of the extract with anti-inflammatory activity in inflammatory processes local of the in vivo models used, in this way, the anti-inflammatory activity observed may not be associated with direct inhibition of $\mathrm{PLA}_{2}$ activity. In spite of the exclusion of direct effect on $\mathrm{PLA}_{2}$ activity, we cannot discard the possibility of an indirect inhibition of this enzyme as occur with steroidal anti-inflammatory drug as in the case of dexamethasone, that not inhibits directly the $\mathrm{PLA}_{2}$ activity (Flower and Blackwell 1979).

\section{CONCLUSION}

Based on the finding from the preset studies, we can summarize that the Streptoverticillium sp. Z1 in appropriate growth conditions produces metabolites with analgesic and/or anti-inflammatory effects. This anti-inflammatory effect is not due to a direct inhibition of the phospholipase $A_{2}$ enzyme. The anti-inflammatory activity of these metabolites may involve a reduction in the production of various inflammatory mediators including those involved in chemotaxis.

\section{ACKNOWLEDGMENTS}

The authors are grateful to Mrs Ekaterina A. F. B. Rivera and Jackson Nascimento de Lima for technical assistance, Coordenação de Aperfeiçoamento de Pessoal de Nível Superior, Conselho Nacional de Desenvolvimento Científico e Tecnológico, and Fundação de Apoio a Pesquisa da Universidade Federal de Goiás for financial support.

\section{RESUMO}

O Streptoverticillium $s p$. Z1 é um actinomiceto isolado do solo sob vegetação de Cerrado, o extrato desta cepa foi avaliado em modelos de nocicepção e inflamação. O extrato de Streptoverticillium (ExS) 50 e $100 \mathrm{mg}$ / $\mathrm{kg}$ (s.c.) produziu uma inibição significativa das contorções abdominais induzidas por ácido acético, demonstrando um efeito anti-nociceptivo. No teste de flexão de cauda o ExS (s.c.) foi inativo, demonstrando que ExS não contem compostos do tipo opióides com propriedade analgésica central. Nos modelos inflamatórios, ExS 100 e $200 \mathrm{mg} / \mathrm{kg}$ (s.c.) foram capazes de inibir o edema induzido por óleo de cróton e, ExS 200 e $500 \mathrm{mg} / \mathrm{kg}$ (s.c.) inibiram a migração leucocitária na peritonite induzida por carragenina. $\mathrm{O}$ ensaio enzimático da atividade da fosfolipase $\mathrm{A}_{2}$ mostrou que a atividade antiinflamatória de ExS não é devido a inibição direta da atividades desta enzima. Estes resultados sugerem que Streptoverticillium sp. produz metabólitos com efeito antiinflamatório e que estes metabólitos são incapazes de inibir diretamente a enzima fosfolipase $\mathrm{A}_{2}$.

Palavras-chave: Streptoverticillium, efeito antiinflamatório, modelos de inflamação e nocicepção, fosfolipase $\mathrm{A}_{2}$.

\section{REFERENCES}

BALKWILl F, Charles KA AND MANTOVANI AS. 2005 Smoldering and polarized inflammation in the initiation and promotion of malignant disease. Cancer Cells 7: 211-217.

BERKENKOPF JW AND WeICHMAN BM. 1988. Production of prostacyclin in mice following intraperitoneal injection of acetic acid, phenylbenzoquinone and zymosan: Its role in the writhing response. Prostaglandins 36: 693-709. 
BREDHOLT H, FJERVIK E, JOHNSEN G AND ZOTCHEV SB. 2008. Actinomycetes from Sediments in the Trondheim Fjord, Norway: Diversity and Biological Activity. Mar Drugs 6: 12-24.

CHAU TT. 1989. Analgesic testing in animals models. In: Pharmacological Methods in the Control of Inflammation. Alan R Liss, Inc., p. 195-212.

FERRÁNDIZ ML AND AlCARAZ MJ. 1991. Anti-inflammatory activity and inhibition of arachidonic acid metabolism by flavonoids. Agents Actions 32: 283-288.

FlOWER RJ AND BLACKWELL GJ. 1979. Anti-inflammatory steroids induce biosynthesis of a phospholipase A2 inhibitor which prevents prostaglandin generation. Nature 278: 456-459.

GROTTO M AND SULMAN FG. 1967. Modified receptacle method for animal analgesimetry. Arch Int Pharmacodyn 165: 152-159.

HARBERMANN E AND HARDT KL. 1972. A sensitive and specific plate test for the quantification of phospholipases. Anal Biochem 50: 163-173.

HENDERSHOT LC AND FORSAITH J. 1959. Antagonism of the frequency of phenylquinone-induced writhing in the mouse by weak analgesics and nonanalgesics. J Pharmacol Exp Therap 125: 237-240.

HUNSKAAR S AND HOLE K. 1987. The formalin test in mice: dissociation between inflammatory and non-inflammatory pain. Pain 30: 103-114.

INSEL PA. 1990. Substâncias analgésicas-antipiréticas e antiinflamatórias; drogas empregadas no tratamento da artrite reumatóide e da gota. In: HARDMAN JG AND LIMBIRD LE (Eds), Goodman \& Gilman's, As bases farmacológicas da terapêutica, $8^{\text {th }}$ ed., McGraw Hill, New York, p. 421-448.

JANSSEN PAJ, NIEMEGEERS CJE AND DONY JGH. 1963. The inhibitory effect of fentanyl and other morphine-like analgesics on the warm water induced tail withdrawal reflex in rats. Arzneim-Forsch Drug Res 6: 502-507.

Koster R, ANDERSON M AND BEER EJ. 1959. Acetic acid for analgesic screening. Fed Proc 18: 412.

LOBO IB AND Hoult JR. 1994. Groups I, II and III extracellular phospholipases A2: selective inhibition of group II enzymes by indomethacin but not other NSAIDs. Agents Actions 41: 111-113.

MALONE MH. 1977. Pharmacological approaches to natural product, screening and evaluation. In: New natural products and plant drugs with pharmacological, biological or therapeutical activity. Berlin: Edited by H. Wagner and P. Wolf Springer - Verlag, p. 24-53.
MORROW JD AND ROBERTS LJ. 2001. Lipid-derived autacoids: eicosanoids and platelet-activating factor. In: HARDMAN JG AND LIMBIRD LE (Eds), Goodman \& Gilman's, The Pharmacological Basis of Therapeutics, $10^{\text {th }}$ ed., McGraw Hill, New York, p. 669-683.

OSADEBE PO AND OKOYÉ FBC. 2003. Anti-inflammatory effects of crude methanolic extract and fractions of Alchornea cordifolia leaves. J Ethnopharmacol 89: 19-24.

PECKYÑSKA-CZOCH W AND MORdARSKI M. 1988. Actinomycete Enzymes. In: Actiomycetes in Biotecnology. Academic press, p. 219-287.

RATES SMK AND BARROS HMT. 1994. Modelos animais para a avaliação da dor: métodos para triagem de novos analgésicos. Rev Bras Farm 75: 31-34.

REISINE T AND PASTERNACK G. 1996. Opioid analgesics and antagonists. In Goodman and Gilman's, the Pharmacological Basis of Therapeutics, $9^{\text {th }}$ ed., Hardman JG and Limbird L (Eds), McGraw Hill: New York, p. 521-526.

SCHIMMER BP AND PARKER KL. 1996. Hormônio adrenocroticotrópico; esteróides andrenocorticias e seus análogos sintéticos; inibidores da síntese e das ações dos hormônios adrenocorticais. In Goodman \& Gilman, As Bases Farmacológicas da Terapêutica, $10^{\text {th }}$ ed., Hardman JG and Limbird L (Eds), McGraw Hill, New York, p. 1241-1261.

Singh N, Kumar RP, Kumar S, Sharma S, Mir R, KAUR P, SRINIVASAN A AND SINGH TP. 2009. Simultaneous inhibition of anti-coagulation and inflammation: crystal structure of phospholipase $\mathrm{A}_{2}$ complexed with indomethacin at $1.4 \mathrm{~A}^{\circ}$ resolution reveals the presence of the new common ligand-binding site. J Mol Recognit 22: 437-445.

Tubaro A, Dri P, Delbello G, Silli C AND Logia RD. 1985. The croton oil ear test revisited. Agents Actions 17: 47-49.

VACHER PJ, DuchÉNe-MARUllaZ P AND BARBOT P. 1964. A propos de quelques produits usuels - comparaison de deux methodes d'étude des analgésiques. Med Exp 11: 51-58.

ZANINI JCJ, MEdeIRos YS, CRUZ AB, Yunes RRA AND CALIXTO JB. 1992. Action of compounds from Mandevilla velutina on croton oil-induced ear edema in mice. A comparative study with steroidal and nonsteroidal antiinflammatory drugs. Phytother Res 6: 1-5. 